\title{
EFL Teaching and Learning at a Vietnamese University: What Do Teachers Say?
}

\author{
Hong Thi Nguyen ${ }^{1}$, Heather Fehring ${ }^{1} \&$ Wendy Warren ${ }^{1}$ \\ ${ }^{1}$ School of Education, RMIT University, Melbourne, Australia \\ Correspondence: Hong Thi Nguyen, School of Education, RMIT University, Melbourne, Australia. E-mail: \\ nguyenhong2510@yahoo.com.vn
}

Received: September 10, 2014 Accepted: October 11, 2014 Online Published: December 17, 2014

doi:10.5539/elt.v8n1p31 URL: http://dx.doi.org/10.5539/elt.v8n1p31

\begin{abstract}
This paper reports part of a study that documents the factors affecting the efficacy of teaching and learning English as a Foreign Language (EFL) in Vietnamese higher education from the teachers' perspectives. Individual face-to-face semi-structured interviews were conducted with twelve EFL teachers at Ho Chi Minh City University of Technology (HUTECH), Vietnam. The study explored both positive factors and negative factors affecting teaching quality. The findings show that an updated syllabus, modern teaching methods, and adequate facilities and equipment are positive factors identified by the teachers. Nevertheless, there are still many negative factors hindering the efficacy of English teaching and learning, including: insufficient time for English subjects; lack of speaking component in tests and examinations; unequal students' English abilities; large class sizes; limited support from university leaders; and students' limited efforts and motivation. The teachers were also given the opportunity to express their expectations about an ideal EFL training program, which included: a balance between financial profit and education quality; more independence for teachers and students in teaching and learning; placement tests; good and enthusiastic teachers; well-equipped classrooms; small class sizes, and student autonomy.
\end{abstract}

Keywords: English teaching, EFL, teachers' perspectives, higher education, Vietnam

\section{Introduction}

English as a foreign language (EFL) has been taught widely as a compulsory subject in many educational institutions in Vietnam, from primary schools to tertiary institutions. The efficacy of English teaching and learning attracts a lot of interest from Vietnamese people and society. Vietnamese government has set out a number of policies and initiatives in order to improve the quality of EFL teaching and learning in Vietnamese education system. However, it seems that there have been a number of challenges for EFL teachers, and a lot of problems inhibiting EFL teaching and learning in Vietnam.

\section{Teachers' Beliefs and Language Teaching}

A lot of effort has been expended to uncover teachers' beliefs in language teaching (Borg, 2006; Chen \& Goh, 2011; Mangubhai, Marland, Dashwood, \& Son, 2004), and teachers' beliefs have a great influence on their teaching practices (Borg, 2003; Chen \& Goh, 2011). According to Williams and Burden (1997), "teachers' deep-rooted beliefs about how languages are learned will pervade their classroom actions more than a particular methodology they are told to adopt or course book they follow" (p. 57). Yilmaz (2011) found that teachers rate themselves to be more efficacious in instructional strategies than in class management or student engagement. Teachers also perceive themselves to be better in reading and speaking skills than in writing and listening skills, and tend to use communication-oriented strategies more than grammar-oriented strategies. It is hypothesized that the more proficient the teachers believe themselves to be in the four macro skills (listening, speaking, reading, and writing), the more efficacious they feel.

\section{Teachers' Perspectives in English Language Teaching}

Teachers' perspectives have been explored in many various aspects of English language teaching. Teachers' challenges in English language teaching attract a great deal of research interest and discussion from educators and scholars. Teaching practices can be affected by many factors, and recognizing the challenges that teachers encounter in their teaching is very important. It not only helps teachers to employ appropriate teaching 
techniques to improve their professional practice but also encourages teacher educators to design effective teacher preparation and training programs to reduce the teachers' difficulties and increase the quality of teaching (Chen \& Goh, 2011).

Of the challenges that teachers face, the exam-oriented education system has been identified as a barrier to the teaching of communicative language. Teachers and students tend to spend class time on practicing tasks for form-based exams instead of focusing on activities to improve students' communicative competence (Gao, 2012; Ming \& Jaya, 2011; Pan \& Block, 2011). The lack of speaking tests in examinations has been identified as one of the reasons hindering teachers from teaching oral English because both students and teachers are not motivated to teach and learn English speaking skills if it is not included in the exams (Chen \& Goh, 2011). In addition, insufficient teaching time for English subjects makes it difficult for teachers to achieve their teaching targets, especially in improving students' speaking and listening skills (Chen \& Goh, 2011; Ming \& Jaya, 2011). The efficacy of class activities is also inhibited by students' resistance to class participation (Chen \& Goh, 2011; Ming \& Jaya, 2011) and teachers' lack of knowledge and skills (Chen \& Goh, 2011; Ming \& Jaya, 2011). In addition, English language teaching teachers have to face difficulties such as: large class sizes(Aduwa-Ogiegbaen \& Iyamu, 2006; Byun et al., 2010; Chen \& Goh, 2011; Ming \& Jaya, 2011); students' unequal English levels (Chen \& Goh, 2011; Ming \& Jaya, 2011); inadequate facilities and equipment (Aduwa-Ogiegbaen \& Iyamu, 2006; Chen \& Goh, 2011); and a lack of an English-speaking environment (Chen \& Goh, 2011; Ming \& Jaya, 2011).

Teachers' professional development is also an issue attracting concern from scholars and researchers. Inadequate teacher training has been identified as a hindrance to the quality of English language teaching (Ming \& Jaya, 2011). Professional development for teachers has been recommended as one of the solutions for education quality (Mathew \& Alidmat, 2013; Yilmaz, 2011).

Teachers' professional development is examined in depth by Alkhawaldeh (2011). The most common professional needs of English as a foreign language teachers include: building effective curriculum with teachers' contributions; providing effective instructional media and facilities for English teaching and learning; developing learners' ability in using English as well as their motivation and attitudes toward English; having training courses to mix with native English speaking communities; using appropriate teaching methods; understanding teachers' new roles as facilitators; a counselor and a director in language classroom; and conducting effective in-service training programs for teachers. Moreover, the study also emphasized the need to have teachers involved in collaborative learning and critical evaluation for: improving their teaching; developing teachers' motivation; equipping teaching labs to create a natural language learning environment; reducing class sizes; building curriculum that respects the learners' actual needs; teachers' societal and cultural beliefs; the need to contact learners' parents to understand their attitudes towards the learning English; and the need to abandon traditional teaching methods and apply various and updated teaching methods to meet learners' different needs and learning styles.

Many issues relating to English language teaching in Vietnam have been explored and discussed by scholars and educators, but limited research studies of EFL teaching in Vietnamese higher education have been conducted. This paper provides insight into the efficacy of English language teaching at a Vietnamese university from the teachers' perspectives.

\section{The Study}

The data presented in this paper were generated by a larger study of factors affecting EFL teaching and learning that involved the participation of two managers, 12 teachers, and 272 students at Ho Chi Minh City University of Technology (HUTECH). Both quantitative and qualitative data were obtained through the following data collection techniques: questionnaires, semi-structured interviews, and non-participant observations. This paper focuses on the data obtained from the semi-structured interviews that were designed to answer the following question: What are the factors affecting EFL teaching and learning in HUTECH from the teachers' perspectives?

\subsection{Participants}

Twelve EFL teachers teaching non-major English at HUTECH, both full-time and part-time, were invited to participate in the study. The participation of these teachers was voluntary, and their ages ranged from 28 years to 64 years. The experience of these teachers in English teaching was varied, from six years to 44 years, and in many different locations. The most common teaching locations were colleges, universities, and foreign language centers. Some teachers also had experience teaching English at primary schools, private companies or institutions. All of these teachers also had a great deal of experience in teaching English at HUTECH, from at least four years to 18 years. Some teachers reported that they have taught at HUTECH since HUTECH was established in 1995 until the present. 


\subsection{Data Collection}

Individual face-to-face semi-structured interviews were conducted to explore teachers' beliefs and expectations of EFL teaching and learning at HUTECH. Each interview lasted around 45 minutes. All interviews were tape-recorded with the consent of participants and then fully transcribed. The researcher did the transcribing herself to ensure that all meanings were obtained exactly and the validity of the data was ensured. The main themes of the interviews were closely related to the research question: factors affecting the activity of EFL teaching and learning at HUTECH.

\subsection{Data Analysis}

The teacher participants were coded using the identification numbers in Table 1 below.

Table 1. Coding for interview participants

\begin{tabular}{lll}
\hline Participants & Identification numbers & Interview dates \\
\hline Teacher 1 & T1 & 07 April 2012 \\
Teacher 2 & T2 & 19 April 2012 \\
Teacher 3 & T3 & 25 April 2012 \\
Teacher 4 & T4 & 18 May 2012 \\
Teacher 5 & T5 & 23 May 2012 \\
Teacher 6 & T6 & 29 May 2012 \\
Teacher 7 & T7 & 03 June 2012 \\
Teacher 8 & T8 & 06 June 2012 \\
Teacher 9 & T9 & 09 June 2012 \\
Teacher 10 & T10 & 15 June 2012 \\
Teacher 11 & T11 & 20 June 2012 \\
Teacher 12 & T12 & 28 June 2012 \\
\hline
\end{tabular}

The instructions for qualitative data analysis introduced by Creswell (2009) were used to analyze the transcribed interview data. Initially, the transcripts were read through to identify the main themes, including predetermined themes and any emerging themes. An inductive approach was used to code the data within each main theme. Similar expressions were grouped into sub-themes and were labeled to describe their content. Interpretations of the results were then made in narrative passages, and the responses from the teachers were quoted to provide evidence for the analysis and findings. The answers to the interview questions extracted from the interview transcriptions were coded as: Interview excerpt T1.07.04.2012.19. This code means that this excerpt was extracted from line 19 of the transcription of the interview with Teacher 1 on 7 April 2012.

\section{Findings}

\subsection{Teachers' Educational Background}

All teachers interviewed had qualifications that were specialized in English teaching and provided by domestic and foreign universities. Nine had MA degrees, most from Australian universities that run training cooperation programs in Vietnam (University of Canberra, Curtin University of Technology, and Victoria University). Other teachers studied MA courses provided by quality universities in Vietnam, such as: HCMC University of Social Sciences and Humanity, and HCMC Open University.

The majority of the teachers interviewed shared the view that, at the time they were students, the facilities and materials for teaching and learning English were not as adequate as at present. The main materials and equipment for English teaching and learning at that time were cassette tapes, course books, blackboards, chalk, and handouts. Some teachers revealed that the cassette tapes were outdated, which made it difficult to practice listening activities. Teacher 2 said:

I studied bachelor more than 20 years ago. At that time, many things were inadequate: books, facilities. Even photocopiers were very rare, and I only knew about what photocopiers are when I nearly graduated. We found it difficult to learn listening due to the lack of cassettes. Even in a family, there was only one cassette, and we were afraid of making it out of work if we listened a lot. Therefore, the time for listening practice was limited. (Interview excerpt T2.19.04.2012.10)

The teachers also mentioned that they did not have many opportunities to practice speaking English. Most of 
them only practiced during classes or with teachers and friends, while some of them practiced at home by talking to themselves or roommates. They sometimes went to English-speaking clubs, but reported that most attendees were Vietnamese and that there were few, or even no, foreigners. This meant they did not have enough opportunities to speak with foreigners, especially native English speakers, to improve their communication skills. Only one teacher studying in America had the opportunity to communicate a lot in English, inside and outside class.

At the time these teachers were students, they were very serious about studying and tried hard. They followed what their teachers said, learned what their teachers taught in the class, and reviewed the lessons and did a lot of grammar exercises at home. They learned vocabulary and grammar quite well, but their listening and speaking skills were not very proficient. Teacher 9 explained:

About vocabulary, we learned in system, looked up new words in dictionary, wrote them down in notebooks, learned in family words, synonyms and antonyms, read stories to remember vocabulary, so we had a great amount of vocabulary. In general, about vocabulary and grammar structures, we studied harder and better than students nowadays, but about listening and speaking, due to the lack of opportunities and equipment, students at that time were not good compared with students nowadays. If at that time we had approached a lot of information and technology like today, I think we would have studied better and more effectively. (Interview excerpt T9.09.06.2012.13)

The teachers admitted that speaking and listening were the two aspects of learning English that they were most afraid of as students. However, for some teachers, that was the reason motivating them to try harder to improve, and even become teachers specializing in teaching speaking and listening skills. Teacher 11 shared:

At the time I was a student, I only like learning grammar and reading, and did not like speaking and listening because I did not practice a lot and was not confident about these skills. But now, as a teacher, I prefer teaching and listening because I have experienced difficulties in studying these subjects and can understand and know how to help students overcome difficulties. (Interview excerpt T11.20.06.2012.23)

\subsection{Positive Aspects of EFL Teaching and Learning at HUTECH}

All essential aspects related to the activity of EFL teaching and learning at HUTECH were explored in depth during the interviews with the teachers. The teachers openly discussed the both positive aspects and negative aspects of teaching English. The positive aspects mentioned by the teachers were related to the syllabus, teaching methods, facilities, and equipment, and some support from HUTECH leaders.

\subsubsection{Syllabus}

All teachers said that they had no complaints about the syllabus because it was designed by a group of world-experts in language education, and it had all language skills and knowledge covered. The lessons were arranged logically and systematically, and it was convenient for teachers and students to use. In addition, when discussing about the syllabus in general, the teachers pointed out that each syllabus had its own advantages and disadvantages, and the important thing was how the teachers could exploit and adapt it in appropriate classes and contexts.

In general, teachers were happy with the syllabus currently used at HUTECH. Only one minor thing mentioned by one teacher was that the managers should arrange and divide the syllabus up over the semesters more appropriately to suit the students' levels of English abilities. For example, students were assigned to study American Headway 2 (Soars \& Soars, 2009a), American Headway 3 (Soars \& Soars, 2009b), and half of American Headway 4 (Soars \& Soars, 2009c) in five semesters. This meant that in each semester, students studied half of each book. Teacher 6 said:

American Headway, new edition is up to date, covers all skills. Its content and lessons are designed well. Book 1 and book 2 are all right, but book 3 and book 4 is quite high for students' level in HUTECH. Few students can follow. So, we should begin with book 1 first, then book 2, then book 3 so that students can gradually follow. (Interview excerpt T6.29.05.2012.31)

Although this idea was raised by only one teacher, it was quite interesting and a reasonable suggestion. Therefore, it was worth considering by managers responsible for English training at HUTECH.

\subsubsection{Various and Updated Language Teaching Methods}

The results from the interviews with teachers showed that the methods they used for English teaching were varied, and depended on each class and each skill they taught. Seven out of twelve teachers preferred communicative language teaching and a student-centered approach. The teachers tried to manage their time so 
that students had the opportunity for participating in communicative activities in classes. Teacher 6 said:

I tried to let students communicate a lot. I use CLT in teaching all skills, especially in speaking and listening. Even in teaching grammar, I also let them practice in pairs, ask them to use the structures they have learnt to ask and answer. Similarly, in reading, I also ask students to ask and answer the questions in books. Generally, I want to improve students' communication in class. (Interview excerpt T6.29.05.2012.36)

However, some other teachers believed that it was not good to advocate for any single method and preferred that teaching methods should be varied. For different classes and different lessons, different methods should be used. Teachers should also use a combination of methods to exploit the advantages of each method, and to make the lessons taught most effective. In discussing the use of different methods in classes, Teacher 2 pointed out:

I think like doing business, we should make customers happy by meeting their requirements. In fact, are our students customers? Yes, they are customers. So, in education, we should treat students like our customers, respect them and teach what they need. Do not think that we should always apply Communicative Approach while it was not suitable for our class. So, if the teachers should use CLT or Grammar Translation Method depends on the specific class. It must be appropriate with context, with real classes. (Interview excerpt T2.19.04.2012.65)

Generally, the teachers thought critically about the methods they use for their classes. Despite their preferred methods, the most common belief among the teachers in the interviews was that the methods they chose for their classes were the most appropriate ones and would bring most benefits to their students.

\subsubsection{Good Facilities and Equipment}

Most teachers contended that the facilities and equipment at HUTECH were adequate and better than those at almost all other universities in Ho Chi Minh City, especially when compared with public universities. Some universities do not have their own campuses and have to rent rooms or buildings for teaching and learning activities. Furthermore, their facilities were very limited. In general, HUTECH classrooms were considered better-equipped than many other universities in Vietnam.

An aspect that made the majority of teachers satisfied was that all rooms were equipped with data projectors. Most teachers said that the data projectors were useful for their English teaching activities because they helped the teachers make the lessons more interesting and effective by using audio and video resources, and by providing clear and colorful pictures or images on the screen. They also helped to save class time and attract more focus from the students. Teacher 7 explained:

Data projectors and computers were necessary and helpful for my teaching. For example, when teaching about English in hotels, I showed the video clips about the situations and conversations in hotels so that the students can see and learn the authentic language. And then, they can role play to practice speaking. (Interview excerpt T7.03.06.2012.39)

The furniture, such as chairs and tables, was highly appreciated by the teachers. They said that most chairs and tables at HUTECH were new and in good condition. The chairs and tables were checked and replaced annually so that they can meet the requirements of the HUTECH leaders.

\subsubsection{HUTECH Leaders' Support in Increasing Time Amount for English Subject}

One noticeable point mentioned by the teachers was that the time allocated for the English teaching had been increased from three semesters to five semesters from last year. It is hard to say if the amount of time increased was enough or not, but any way, this was a good signal which demonstrates that the HUTECH leaders had acted on their concerns and considerations for the improvement of English teaching and learning in HUTECH.

\subsubsection{HUTECH Leaders' Support in Increasing Salary}

Eight out of twelve teachers in the interviews agreed that the salary in HUTECH was higher than other universities in Ho Chi Minh City in particular and in Vietnam in general, especially when compared with public universities. Recently, HUTECH implemented a new organizational system in which the salaries for staff members and teachers were increased. However, staff and teachers were also assigned more tasks and duties. Nevertheless, increasing salaries was a positive move that could motivate the teachers to devote more to their teaching career.

\subsection{Negative Aspects of EFL Teaching and Learning in HUTECH}

Besides positive aspects, the teachers also discussed some negative aspects of the English training program at HUTECH. Most negative aspects were related to the curriculum, class sizes, facilities and equipment, support 
from HUTECH leaders, teacher recruitment, and the students' attitudes and motivation. Details of these negative aspects as well as teachers' suggestions are discussed below:

\subsubsection{Insufficient Time Allocated for English Teaching}

As discussed earlier, the teachers appreciated the support of HUTECH when increasing the allocation of time for English from three semesters to five semesters. However, some teachers stated that it was still not enough. According to them, the time allocated for English should be increased to seven or eight semesters so that students could have steady English learning progress during their time at the university until they graduated. The teachers believed that this would make it easier for students to apply for jobs when the English knowledge obtained at the university was still fresh.

\subsubsection{Not Enough Time for Teaching English Speaking and Communication}

Some teachers said that the current amount of time for English was enough for teaching macro skills if the teachers had good time management, effective teaching methods, and if the students worked hard. However, the majority of teachers said that they did not have enough time to teach their students speaking and communication skills although they really wanted to undertake these activities. The time amount allocated for English in each semester was enough if the teachers only taught students grammar, vocabulary, reading, writing, and listening. It was not enough time if the teachers wanted to include speaking and communication activities. Teacher 10 raised his concerns:

The thing I consider is that if teachers only teach grammar or writing, students cannot speak English after they leave the university. So, what I mean is that the university should focus on teaching speaking skill so that the students can speak English inside and outside class. Nowadays, a lot of university students graduating without being able to communicate English well with foreigners because they did not enough time to learn speaking English at the universities. (Interview excerpt T10.15.06.2012.53)

In addition, it was suggested that instead of waiting for the time amount to be increased by HUTECH leaders, the teachers could find ways to help their students improve speaking skills. Teacher 5 shared her idea as follows:

To have time for speaking practice, the teachers in classes should decide by themselves, be flexible to remove some parts which are not very important, and let students do some parts at home by themselves, and use the time for teaching speaking. (Interview excerpt T5.23.05.2012.32)

\subsubsection{No Speaking Tests in the Examinations}

One of the common complaints raised by the teachers was that the content of the tests and examinations did not cover all macro skills. There was a paradox within the management and direction of HUTECH leaders. Although their purpose was to equip students with English communication skills for future employment after graduation, they did not agree to include a speaking section in the tests and examinations. The main reason was that the speaking tests cost time and money. However, it was believed that, without speaking tests, the teachers and students did not have motivation for teaching and learning these skills. Instead, they focus on the knowledge areas and skills that would be tested so that the students could pass the exams. Teacher 4 explained further:

The final examinations focus on grammar and writing. So, if the teacher teaches students speaking skills, students may think that the teacher is not good because what he or she teaches is not applied in the examinations. So, we should change the curriculum so that the final examinations should test not only grammar and writing but also speaking skill. (Interview excerpt T4.18.05.2012.19)

Teacher 12 expressed other opinions in relation to this point:

If we want to teach students speaking, there should be more time for English subject, and the speaking tests must be included in the exams. When the speaking tests are included in the exams, the students will have to try hard to improve speaking and communication skill to pass the exams, and hence, their speaking and communication skill will be better. (Interview excerpt T12.28.06.2012.26)

Therefore, it is suggested that HUTECH should have clear purposes and objectives in its English training program by providing a systematic curriculum in which the training content and testing content must be in accordance to serve the common purposes and objectives.

\subsubsection{Not Beneficial for Students}

In discussion about the effectiveness of the English training program at $\mathrm{HUTECH}$, some teachers said that it was not profitable and not beneficial for the students. They shared their concerns about what the students could achieve after graduation and if the English knowledge they received during their student time in HUTECH could 
be helpful for them in their life and careers and for society. They said that the university still focused on what the students learn each year, but did not focus on what the students can achieve each year and after graduation. Teacher 1 expanded on this point:

All teachers concern about how to help students, but there is not enough time for them to do what they want. In my opinion, there is a need to reconsider the curriculum. We cannot reduce the time amount for English because it is not much, but we should reduce the knowledge amount the teachers need to provide in each lesson, so that the teachers have more time for the students to practice and use the language they learnt. Generally, we should focus on what the students can gain after their lessons. (Interview excerpt T1.07.04.2012.19)

\subsubsection{Unreasonable Schedule and Timetable}

The schedule and timetable was also a problem discussed by the teachers. It was pointed out that normally, the students studied English once a week during a 15-week semester. However, some classes were scheduled to study English twice a week and these students, therefore, finished the course before the end of semester. This would be normal if the students were scheduled to study in two sessions that were not too close so that the students had time to review the lessons between the sessions and absorb the knowledge provided. However, the students had English classes scheduled on two days close together and this was believed to be ineffective for the students' learning. Moreover, it was reported that the students had to study many subjects each day and this was believed to make them tired and they could not concentrate well on their subjects in general and on English in particular.

\subsubsection{Unequal Students' English Levels}

Four of the twelve teachers interviewed reported that the English ability of the students in the same class was not at the same level. Having students with different English levels in the same class made it difficult for the teachers to conduct their teaching activities. In the same class, with the same knowledge content provided, some students could understand but other students could not. Teacher 11 explained the difficulties of a teacher when teaching a class with students' of various abilities:

If the teacher uses the activities and tasks appropriate for the good students, the weak students could not follow and would be de-motivated. But if the teacher teaches simple knowledge appropriate for the weak students, the good students will get bored, and it also wastes their time and money in a class like that. (Interview excerpt T11.20.06.2012.45)

\subsubsection{Big Class Sizes}

One common complaint raised by the majority of the teachers was that, when compared with the requirements of a standard English class, the number of the students in English classes in Vietnam generally and in HUTECH in particular was quite large. At HUTECH, there were about 50 to 55 students in each English class, and this was believed to reduce the quality of English teaching and learning. In a large class, it was difficult for the teachers to control and manage the class well. It was also especially difficult and time-consuming for the teachers to conduct communicative activities such as pair work and group work. The teachers said that it was impossible to bring the highest benefits and effectiveness to the students in such crowded classes.

\subsubsection{Limited Programs for Teachers' Professional Development}

It was found that the programs and activities for the professional development of English teachers at HUTECH were very limited. There were no training courses, workshops, or seminars for English teachers to further their careers. Teacher 11 said:

To keep good teachers and improve the quality of teaching, we should have training courses or workshops for teachers, but in fact we do not have these programs. So, we need to do this, and do effectively so that the teachers realize they are useful for them, and they will participate. I myself have been to some workshops outside this university, but they are not effective, so I do not go there any more. (Interview excerpt T11.20.06.2012.101)

\subsubsection{Insufficient Response Time to the Teachers' Problems}

The teachers were critical of the HUTECH leaders' reactions to the teachers' problems, commenting on their slowness in addressing teachers' problems. When the teachers had problems using technical equipment, or when they required some support from the facilities and equipment office, they often had to wait a long time until their problems were solved. Some problems were not solved until the end of the school year. Teacher 10 complained:

Sometimes the OHPs did not work well, but when I called the maintenance staff, they said that they would come, but we had to wait for so long. I prepared my lesson in my laptop, when the OHPs did not work suddenly but were not fixed right away, I could not continue my lesson well as intended. (Interview excerpt 


\section{T10.15.06.2012.81)}

\subsubsection{No Funds for English Improvement Activities Outside Class Time}

In discussion about the support from HUTECH leaders, the teachers complained that there were no funds for activities or programs outside class time to help the students improve their English. It was said that there was a need to have an effective educational playground for the students with useful activities outside class time, such as English clubs, English speaking contests and English music festivals. To make the activities work well and be conducted regularly, financial support from HUTECH leaders was considered very important. It was claimed that HUTECH leaders used to have a small fund for these programs, but this fund was discontinued last year. Teacher 7 claimed:

Academic activities outside class time not only help students improve English but also provide them with opportunities to make friends and exchange information and knowledge. They can share each other the ways they improve English. So, the students can learn from each other in these academic activities. However, there are no funds from HUTECH. So, we cannot hold the programs regularly and effectively. (Interview excerpt T7.03.06.2012.57)

\subsubsection{Unprofessional Recruitment}

Some teachers said that the recruitment process at HUTECH was not very professional. The university had an official and formal recruitment program for full-time teachers. However, the recruitment process for part-time teachers was mostly based on relationships. It was claimed that by using this recruitment process, the teachers' abilities could not be checked because the teachers did not have to demonstrate their teaching performance for selection. Teacher 11 shared her viewpoint:

The recruitment procedure for part-time teachers is not professional and not competitive. When the teacher performance is not assessed in the recruitment procedure, the quality of the teachers selected is not assured. Therefore, the quality of English teaching in HUTECH in general is also affected. (Interview excerpt T11.20.06.2012.97)

\subsubsection{Students' Attitudes and Motivation for English Study}

Nine out of the twelve teachers said that the students' attitudes towards English depended on the majors they studied. Students from different major disciplines had different attitudes towards English. In general, students from majors related to economics, such as business, finance, and accounting, were interested in English and studied English better than the students from majors related to technology, such as mechanical engineering and civil construction engineering. All the teachers complained about the attitudes towards English and the English abilities of the students from interior decoration majors and fashion design majors. Teacher 7 said:

I use the same tasks for the students at different majors, and see that the students from business or finance or IT are more interested in doing the tasks and do well while the students from majors such as civil construction or fashion design are not very interested and do not finish the tasks well. (Interview excerpt T7.03.06.2012.69)

However, it was also pointed out that, even in the classes with students from the same major, the English abilities and the attitudes of the students varied. Teacher 2 explained:

The students in majors like civil construction, fashion design are very lazy. But it doesn't mean that all the students in one class are the same. In one class, there are also good and bad students. For example, last semester, I taught a class majoring in fashion design, and saw that there were also some good and hard-working students in that class. So, the students' attitudes depend on classes, and on individual students. (Interview excerpt T2.19.04.2012.90)

As well as discussion about the students' attitudes towards English, the reasons for the students' low motivation towards English were also explored. According to the teachers, there were many reasons demotivating the students from learning English. The most mentioned reason was that the students in some majors did not think English would be important for their majors and their future careers. Teacher 6 shared:

The students in some majors requiring English a lot for future jobs like business, accounting had positive attitudes, and study well, but the students from majors like electronics, civil construction, fashion design may think that English is not very useful for their future. They think that if they do not work for foreign companies, they can work for Vietnamese companies, so they are not positive in learning English. (Interview excerpt T6.29.05.2012.58)

In addition, the students were de-motivated from learning English because they lacked basic English knowledge. Some students did not study English hard when they were at junior and senior secondary schools, and, therefore, 
they did not have a basic English background to continue their English study university. Some other students came from remote or rural areas where English was not taught very effectively. In some areas of Vietnam, the students were not taught English at all. Instead, they studied French as a foreign language in their junior and senior secondary schools. Some students only started studying English when they were at senior secondary school. Therefore, when these students came to the university, it was hard for them to follow the English program for higher education students. Other reasons de-motivating the students from their English study were that the students were not confident when studying in the same class with more advanced students and that the teachers were not enthusiastic.

The teachers were also asked about solutions to help the students become more interested and motivated in their English study. Most of the teachers expressed that they would try to find out the reasons for poor motivation so that they could implement suitable solutions. They said that they would explain to the students the importance of English and give them the advice and strategies to learn English. In addition, it was suggested that when the students were not motivated or interested, the teachers should also use self-evaluation to see if that increased the students' motivation and interests or not. Teacher 1 said:

I think the teacher and the university also had strong effects on the students. So, the most important thing is that at the beginning of the course, the teacher must make the students motivated, make them interested and have inspirations. (Interview excerpt T1.07.04.2012.58)

Moreover, it was pointed out by the teachers in the interviews that the teaching styles and methods also influenced the students' attitudes towards study. For different types of students, different methods should be used. Teacher 7 shared her ideas:

Due to the difference in the students' English ability, I use appropriate techniques for each group of student. For the majors like business, where most students are good and only some students are weak, I can let weak students work in groups with good students and ask them to help and support each other, and I see that they can do well. But for some majors like civil construction, where only some students are good, I use more simple tasks for the whole class, but still have to assure that the basic knowledge required for the course would be covered. (Interview excerpt T7.03.06.2012.74)

Relating to this point, Teacher 5 also shared her experience:

For weak students, I focus more on them, ask them simple questions to encourage them, because if I asked difficult questions, they cannot answer and will lose their interests. I also encourage them by giving them compliments when they answer the questions or do the tasks well. (Interview excerpt T5.23.05.2012.38)

In addition, it was agreed by the majority of the teachers that the ability to create a happy and interesting atmosphere in the class was also important in increasing the positive attitudes of the students. The teachers also shared their experiences in making the class interesting. Some teachers said that they used games or songs to make the class happy and relaxed. Some other teachers revealed that they used a learner-centered approach that encouraged students to reduce the teacher's lecturing time and increase the students' talking time. They believed that this gave the students a chance to speak, discuss and work together and would not feel boring or sleepy. Teacher 11 reported:

Sometimes, I let the students design their own communication activities, and I am surprised when they can do that and even do very well. As students, they understand each other, and therefore, they design the tasks or activities which are appropriate for their style, age and interests. (Interview excerpt T11.20.06.2012.88)

\subsection{Teachers' Expectations and Suggestions for an Ideal EFL Training Program in HUTECH}

The teachers were also asked about their opinions on an ideal EFL training program. Interestingly, all the teachers admitted that, in the Vietnamese higher education context in general, and at HUTECH in particular, it was very difficult, or even impossible, to have an ideal EFL training program that met international standard requirements. Therefore, the teachers could only suggest a possible ideal program that matched the ability of HUTECH leaders.

\subsubsection{Balance between Financial Profit and Education Quality}

It was reported that HUTECH leaders focused too much on financial profit, and this was believed to affect the quality of EFL teaching and learning at HUTECH. Therefore, the teachers hoped that HUTECH leaders could manage and balance financial profit and educational quality. In fact, it was very difficult to achieve this because the above two concepts seemed to be in conflict with each other. However, teachers seemed convinced that if the HUTECH leaders had more effective management strategies, they could be able to solve this problem. Teacher 
10 shared his ideas:

Currently, we have many teaching staff who does not work very effectively. So, we should refine the teaching staff team so that we can reduce the cost. We should pay higher salary for the good teachers and require more contributions from them. By doing this, we will have an effective teaching staff team and can solve the problem of financial profit and education quality. (Interview excerpt T10.15.06.2012.186)

\subsubsection{More Independence for Teachers and Students}

The teachers said that an ideal training program was the one where the teachers and the students were given enough freedom and independence in their teaching and learning. It was pointed out that at HUTECH, the textbooks and the lessons were assigned for the teachers by the university. The only choice left for the teachers was the teaching method. As a result, the teachers had to assign their students fixed tasks to complete the syllabus and the exams. The teachers and the students did not have much independence or flexibility in their teaching and learning. In discussion about this point, Teacher 6 suggested:

We should only give the overall target of each semester, then let the teachers free to choose ways to obtain that target. The teachers should have rights to choose books appropriate for their classes, their students'levels, what skills to be taught more. In their classes, the teachers should have rights to adjust their teaching schedule, decide what lessons to teach first, what to teach later. So, should be flexible, give the teachers more independence so that the teachers can give their students more independence. That will help them feel comfortable, and therefore, the teaching and learning will be more effective. (Interview excerpt T6.29.05.2012.101)

\subsubsection{English Program Should Be Taught before Main Program}

At present, at HUTECH, the students studied English at the same time as their other major subjects. It was said by some teachers that the English teaching and learning at HUTECH would be improved if the English program was taught before the main program. Teacher 3 pointed out:

We can adapt the model of FPT University. The program in FPT university is very effective. The students do not study English at the same time with their major subjects. The students who meet the English requirement can start the main program immediately, but the students who do not meet the English requirement have to study English full time during one year, and after they meet the English requirement, they are allowed to study major subjects. If not, they continue studying English until they meet the requirement. (Interview excerpt T3.25.04.2012.96)

\subsubsection{Placement Tests}

It was suggested that HUTECH should have placement tests to categorize the students and place them into appropriate classes. If the students' English level in a class were to be equal, it would be easier for the teachers to conduct their teaching activities and apply their teaching methods more effectively.

\subsubsection{Good and Enthusiastic Teachers}

The role of the teachers was considered very important in creating a good English training program at HUTECH. Due to the busy teaching schedule, the teachers sometimes felt tired and did not invest much time in their lessons. They also lost their enthusiasm and passion for their career. Some teachers came to the classes without good preparation, without technical equipment and teaching aids, except for the book and the tape recorder. To make the teaching more effective at HUTECH, the teachers should be more enthusiastic, more active and should use learner-centered approaches.

\subsubsection{Good Curriculum}

It was believed that a good curriculum was essential for a quality English training program at HUTECH. The syllabus for English teaching at HUTECH was considered adequate, and the teachers did not have many comments on the syllabus, but they expressed concerns about the curriculum. The teachers said that the English curriculum at HUTECH should cover the four core skills, not only in the teaching and learning but also in the examinations. The content being taught and tested should aim to develop the students' communication skills and ability to use English for their future careers.

\subsubsection{Well-Equipped Classrooms}

It was contended that well-equipped classrooms also contributed to the quality of teaching. Therefore, ideal English training at HUTECH should be accompanied by ideal classrooms in which all necessary teaching aids are available. In addition, it was recommended that separate chairs should be used to replace long benches at HUTECH to make it convenient for communication and movement activities. 


\subsubsection{Smaller Class Sizes}

Most of the teachers complained that the number of the students in a class in higher education in general and in HUTECH in particular was quite large. Class sizes ranging from 50 to 60 students were believed to reduce the quality of teaching and learning. It was hard for the teachers to control the students and conduct communicative activities such as pair work and group work. It was also difficult for the teachers to remember the students and their ability as well as their wishes and thoughts so that they can help them effectively. The teachers said that an ideal English class should be around 20 students; however, they understood that it was impossible to have this number. Thus, the teachers said that a class with no more than 30 students at HUTECH would be preferred. Some teachers said that a class with 40 or 50 students was also acceptable, but only if the students' English levels in the same class were equal. Once again, the importance of the placement tests was emphasized.

\subsubsection{Students' Autonomy}

Some teachers were not satisfied with the students' level of autonomy at HUTECH. The teachers felt that an effective English training program required the cooperation of teachers and students. Students' autonomy was considered an important factor contributing to the success and quality of English training programs at HUTECH. Teacher 8 said:

Learners' autonomy is very important, especially at tertiary level. With limited time in class, the teachers cannot provide all knowledge, so they can only provide the main and basic knowledge and instruct the students the ways to develop more by themselves. So, students need to spend more time outside class for self-study, research and improve their knowledge. (Interview excerpt T8.06.06.2012.23)

\section{Discussion}

The results from the study show that compared with many other universities in Ho Chi Minh City, the facilities and equipment at HUTECH are better and adequate for the teaching and learning activities in general and for English teaching and learning in particular. This is due to the efforts from HUTECH leaders who strive to have HUTECH become one of the best-equipped universities in the Vietnamese education system, and step-by-step make HUTECH's brand become recognized as a well-known university, not only in Vietnam but also in South-East Asia.

From a university having to rent campuses and buildings in poor conditions for teaching and learning, HUTECH has developed and currently has three of its own campuses with adequate facilities. When being asked about the facilities and equipment at HUTECH, all of the teachers expressed their satisfaction, and this is believed to be a supporting factor for the activity of teaching and learning. This result seems to be different from the general statement of Vietnam Ministry of Education and Training (MOET) that a lack of facilities is a common situation in the Vietnamese higher education system and that this is one of the factors affecting the quality of teaching and learning in higher education (MOET, 2010). Although HUTECH is a university under the control and management of MOET in general, HUTECH has more freedom in managing its finances compared with public universities. As a private university in the national education system, HUTECH still has to adhere to the ceiling of the tuition fee level set out by MOET (Harman, Hayden, \& Pham, 2010), but HUTECH has freedom and flexibility in financial control and expenses. HUTECH leaders can make their own decisions in financial management and investment. As a result, the facilities at HUTECH have been renovated and equipped by HUTECH's own financial budget under the instructions of HUTECH's leaders without waiting for the approval from MOET. This helps to facilitate the process of equipping and renovation, and makes HUTECH one of the best-equipped private universities in Vietnam.

This result leads us to a broader discussion about the MOET management. As revealed by the teachers in the interviews, the facilities and equipment at HUTECH are better than many other universities, especially public universities. This raises the question: why are the facilities in a private university such as HUTECH are better than the facilities in many public universities? Is it because, as a private university, HUTECH is given more freedom and flexibility compared with public universities? If so, to make public universities better equipped, there should be more freedom and flexibility in the finance and investment given to them by MOET. At present, MOET has the primary role in the control and management of almost all aspects of Vietnamese education (Harman et al., 2010). This is believed to keep the Vietnamese education system in good management. However, if the schools and universities have to strictly follow all regulations and instructions from MOET, they will lose their flexibility and their competitive advantages, both of which are important factors for development.

The results from this study also reveal teachers' viewpoints about the factors inhibiting the quality of English language teaching. With the current teaching time for English, it is impossible for teachers to help students 
improve all English knowledge and skills: vocabulary, grammar, listening, speaking, reading, and writing. Due to the insufficient time available for teaching, the teachers cannot focus on teaching English communication for students, even though they really want to do so. As pointed out by Nguyen, Warren, and Fehring (2014), this is one of the reasons leading to the dominance of grammar-translation method and the limited implementation of communicative language teaching (CLT) in EFL classes. This result is consistent with previous studies that found that insufficient time is one of the problems challenging the quality of English teaching and learning (Chen \& Goh, 2011; Ming \& Jaya, 2011).

The study found that the exclusion of speaking component in the tests is the primary reason hindering the teaching of students' English speaking and communication. This result confirms previous studies that found that the traditional written-form test model that focuses on testing students' linguistic competence rather than communicative competence would lead to the teachers' and students' preference for the exam-oriented teaching in classes (Ming \& Jaya, 2011; Pan \& Block, 2011). The explanations of Pan and Block (2011) about the examination culture in China are also similar to the situation in Vietnam. In Vietnam, the examination culture has been deep-rooted in the people's minds since the feudalism time until now, and examinations have been considered as an important tool to evaluate study success. Written tests are the products of the imperial exams aiming to assess learners' achievements and have been maintained in the Vietnamese education system until now. The examination culture and the written test model are not only issues in Vietnam but also issues in a number of Asian countries and other English as a foreign language country. To motivate the teaching of English speaking and communication, it was suggested that an oral test should be included in the exams (Chen \& Goh, 2011; Ming \& Jaya, 2011).

In addition, the study results echo the findings of Byun et al. (2010) that point out that students from business-related majors have more favorable attitudes toward English than students from engineering or science related majors. It was explained that students from business-related majors consider English proficiency to be helpful for their future career, whereas students from engineering or science classes do not feel that English is a necessity for their field of study and future careers. Therefore, the question raised here is what should be done to help the students from engineering or science majors recognize the benefit of English proficiency for their future career so that they themselves will invest more time in English study? In the researcher's opinion, it is the responsibility of not only teachers but also HUTECH's managers and leaders to conduct activities that aim to increase students' awareness of the importance of English. This can be done formally through meetings, seminars, career consultation sessions conducted by universities, faculties, or it can be done informally through regular talks or advice from teachers.

The findings of this study support previous studies that found that the lack of teacher training and professional development is a de-motivating factor to the quality of English teaching and learning (Gao, 2012; Ming \& Jaya, 2011) and emphasize the importance of teacher professional development (Alkhawaldeh, 2011; Yilmaz, 2011). Yilmaz (2011) found that the more proficient the teachers believe themselves in four macro skills (listening, speaking, reading, and writing), the more efficacious they feel. Therefore, it is important to provide adequate training programs and professional development for teachers so that they will become more proficient in the four macro skills, and this will lead to their strong sense of efficacy.

\section{Conclusion}

The study results have provided a snapshot of the status of EFL teaching and learning at HUTECH from the teachers' perspectives. Besides some positive aspects, there are still many negative aspects that need to be addressed and dealt with. The study also reveals teachers' expectations and suggestions for an ideal EFL training program at HUTECH. Although the study was conducted only at $\mathrm{HUTECH}$, its results may be applicable for other universities in Vietnam, as HUTECH is a university under the management of Vietnam Ministry of Education and Training (MOET). Although HUTECH has freedom in finance management, it still has to follow strictly MOET's training policy and regulations. Therefore, the results from this study are still significant in reflecting the perspectives of EFL teachers and the activity of EFL teaching and learning in Vietnamese higher education.

The results of the study indicate that in order to have quality training in English language teaching, appropriate and effective strategies are needed. As suggested by Mai and Iwashita (2012), to enhance the quality of English teaching, the teachers and the students should not be left alone. There should be efforts and cooperation from administrators, parents and society. 


\section{References}

Aduwa-Ogiegbaen, S. E., \& Iyamu, E. O. S. (2006). Factors affecting quality of English language teaching and learning in secondary schools in Nigeria. College Student Journal, 40, 495+.

Alkhawaldeh, A. (2011). The professional needs of English language teachers at Amman 1st and 2nd directorates of education.(Report). College Student Journal, 45(2), 376.

Borg, S. (2003). Teacher cognition in language teaching: A review of research on what language teachers think, know, believe and do. Language Teaching, 36(2), 81-109. http://dx.doi.org/10.1017/S0261444803001903

Borg, S. (2006). Teacher cognition and language education: Research and practice. London, New York: Continuum.

Byun, K., Chu, H., Kim, M., Park, I., Kim, S., \& Jung, J. (2010). English-Medium Teaching in Korean Higher Education: Policy Debates and Reality. Higher Education: The International Journal of Higher Education and Educational Planning. http://dx.doi.org/10.1007/s10734-010-9397-4

Chen, Z., \& Goh, C. (2011). Teaching oral English in higher education: Challenges to EFL teachers. Teaching in Higher Education, 16(3), 333-345. http://dx.doi.org/10.1080/13562517.2010.546527

Creswell, J. W. (2009). Research design: Qualitative, quantitative, and mixed methods approaches (3rd ed.). Thousand Oaks, Calif.: Thousand Oaks, Calif.: Sage Publications.

Gao, L. (2012). Digital Technologies and English Instruction in China's Higher Education System. Teacher Development, 16(2), 161-179. http://dx.doi.org/10.1080/13664530.2012.667967

Harman, G. S., Hayden, M., \& Pham, T. N. (2010). Reforming higher education in Vietnam: Challenges and priorities. Dordrecht: Springer.

Mai, N. K., \& Iwashita, N. (2012). A comparision of learners' and teachers' attitudes toward communicative language teaching at two universities in Vietnam. University of Sydney Papers in TESOL, 7, 25-49.

Mangubhai, F., Marland, P., Dashwood, A., \& Son, J. B. (2004). Teaching a foreign language teaching: One teacher's practical theory. Teaching and Teacher Education, 20(3), 291-311. http://dx.doi.org/10.1016/j.tate.2004.02.001

Mathew, N. G., \& Alidmat, A. O. H. (2013). A study on the Usefulness od Audio-Visual Aids in EFL Classrooms: Implications for Effective Instruction. International Journal of Higher Education, 2(2), 86-92. http://dx.doi.org/10.5430/ijhe.v2n2p86

Ming, C., \& Jaya, S. G. (2011). Factors Affecting the Implementation of Communicative Language Teaching in Taiwanese College English Classes. English Language Teaching, 4(2), 3-10.

MOET. (2010). Doi moi quan ly he thong giao duc dai hoc giai doan 2010 - 2012. Hanoi: Nha xuat ban giao duc.

Nguyen, H. T., Warren, W., \& Fehring, H. (2014). Factors affecting English language teaching and learning in higher education. English Language Teaching, 7(8), 94-105. http://dx.doi.org/10.5539/elt.v7n8p94

Pan, L., \& Block, D. (2011). English as a "global language" in China: An investigation into learners' and teachers' language beliefs. System, 39, 391-402. http://dx.doi.org/10.1016/j.system.2011.07.011

Soars, L., \& Soars, J. (2009a). American Headway (2nd ed.). Oxford: Oxford University Press.

Soars, L., \& Soars, J. (2009b). American Headway 3 (2nd ed.). Oxford: Oxford University Press.

Soars, L., \& Soars, J. (2009c). American Headway 4 (2nd ed.). Oxford: Oxford University Press.

Williams, M., \& Burden, R. (1997). Psychology for language teachers. Cambridge: Cambridge University Press.

Yilmaz, C. (2011). Teachers' perceptions of self-efficacy, English proficiency, and instructional strategies. (Report). Social Behavior and Personality: An international journal, 39(1), 91-100. http://dx.doi.org/10.2224/sbp.2011.39.1.91

\section{Copyrights}

Copyright for this article is retained by the author(s), with first publication rights granted to the journal.

This is an open-access article distributed under the terms and conditions of the Creative Commons Attribution license (http://creativecommons.org/licenses/by/3.0/). 